\title{
Synthesis and properties of rare earth doped lamp phosphors ${ }^{\dagger}$
}

\author{
S EKAMBARAM and K C PATIL* \\ Department of Inorganic and Physical Chemistry, Indian Institute of Science, Bangalore \\ 560012 , India
}

\begin{abstract}
Red, blue and green emitting lamp phosphors such as $\mathrm{Eu}^{3+}$ doped $\mathrm{Y}_{2} \mathrm{O}_{3}$ (red phosphor), $\mathrm{Eu}^{2+}$ doped $\mathrm{Ba}_{0.64} \mathrm{Al}_{12} \mathrm{O}_{18.64}, \mathrm{BaMgAl}_{10} \mathrm{O}_{17}$ and $\mathrm{BaMg}_{2} \mathrm{Al}_{16} \mathrm{O}_{27}$ (blue phosphors) and $\mathrm{Ce}_{0.67} \mathrm{~Tb}_{0.33} \mathrm{MgAl}_{11} \mathrm{O}_{19}$ and $\mathrm{Eu}^{2+}, \mathrm{Mn}^{2+}$ doped $\mathrm{BaMgAl}_{10} \mathrm{O}_{17}$ (green phosphors) have been prepared by the combustion of the corresponding metal nitrates (oxidizer) and oxalyl dihydrazide/urea/carbohydrazide (fuel) mixtures at $400^{\circ}-500^{\circ} \mathrm{C}$ within $5 \mathrm{~min}$. The formation of these phosphors has been confirmed by their characteristic powder $\mathrm{X}$-ray diffraction patterns and fluorescence spectra. The phosphors showed characteristic emission bands at $611 \mathrm{~nm}$ (red emission), 430-450 nm (blue emission) and 515-540 nm (green emission). The fine-particle nature of the combustion derived phosphors has been investigated using powder density, particle size and BET surface area measurements.
\end{abstract}

Keywords. Combustion synthesis; phosphors; rare earths.

\section{Introduction}

Rare earth activated phosphors have attracted great interest because of their drastic improvements in lumen output, colour rendering index, energy efficiency and greater radiation stability (Koedam and Opstelen 1971; Verstegen $e_{t}$ al 1974; Kunzler et al 1992a; Tews et al 1992). The trivalent rare earth ions in general give line emissions attributed to $4 f$ electrons which are sufficiently protected from perturbations due to the environment of the host matrices. Hence, rare earth activated phosphors lead to high luminescence quantum yield, compared with other phosphors, quenching occurs only at higher-temperatures or higher activator concentrations. Such phosphors find applications ranging from conventional fluorescent lighting (lamp phosphors) to colour TV picture tubes, $\mathrm{X}$-ray photography, luminescence immunoassay, phosphor thermometry, etc (Welker 1991; Blasse 1993). Trichromatic fluorescent lamps with the three components are $\mathrm{BaMgAl}_{10} \mathrm{O}_{17}: \mathrm{Eu}^{2+}$ (blue), (Ce, Tb) $\mathrm{MgAl}_{11} \mathrm{O}_{19}$ (green) and $\mathrm{Y}_{2} \mathrm{O}_{3}: \mathrm{Eu}^{3+}$ (red).

In order to have effective glass coating and optimum brightness, the phosphors should satisfy the following requirements: (a) fine particles $(5 \mu \mathrm{m})$, (b) narrow particle size distribution, (c) large surface area and (d) high purity and homogeneity.

The preparation of phosphors by the conventional solid state method (Smets and Verlijsdonk 1986; Forest and Ban 1971) involves heating the component dry oxides or oxalates at high temperatures with repeated grinding. Due to the refractory nature of rare earth oxides, synthesis by the conventional solid state method requires high temperature $\left(\geqslant 1400^{\circ} \mathrm{C}\right)$ and long processing time which often results in inhomogeneous product and hence leads to localized concentration quenching. Further, use of high temperature results in low surface area with broad particle size distribution.

\footnotetext{
${ }^{\dagger}$ Paper presented at the poster session of MRSI AGM VI, Kharagpur, 1995

*Author for correspondence
} 
Investigations are, therefore, focussed on lowering the preparative temperatures either by flux method (Ronda and Smets 1989; Smets et al 1989) or by wet-chemical methods (Ramussen et al 1985; Hours et al 1992; Rao 1994). A few aluminates can be synthesized at $1200^{\circ} \mathrm{C}$ using $\leqslant 2 \%$ boric oxide as the flux. When the flux content is increased so as to accelerate the reaction, new phases of aluminoborates begin to form, whose fluorescence characterization differ markedly from those of aluminates. The formation of coarse phosphors in the conventional solid state method could be mitigated by these methods which in addition have several advantages in terms of purity, homogeneity and short processing time. Solution routes such as alkoxy method and coprecipitation techniques have been used to prepare these phosphors. Though the wet-chemical methods meet the requirements of phosphors, the processing requires rigorous care like maintaining the $\mathrm{pH}$ as in the coprecipitation technique. Hence, the wet chemical methods are tedious and cumbersome. Therefore, there is a need for an alternative approach to the wet chemical methods for the preparation of lamp phosphors, which not only fulfills the requirements of phosphors but also should be simple and easy to scale-up.

The combustion process pioneered by Patil et al (Patil 1993; Patil and Sekar 1994) has been extensively employed for the instant synthesis of variety of technologically important oxides. The combustion process is of tremendous interest because it offers nonmelt route to synthesize fine particle homogeneous powders. An important feature of the facile process is the utilization of the enthalpy of combustion for the formation and crystallization of powders at low calcination temperature. The cost and effort involved in the combustion process is also low. It was, therefore, considered interesting to see if this solution combustion process could be employed to prepare fine particle $\mathrm{Eu}^{3+}$ doped $\mathrm{Y}_{2} \mathrm{O}_{3}$ (red phosphor), $\mathrm{Eu}^{2+}$ doped $\mathrm{Ba}_{0.64} \mathrm{Al}_{12} \mathrm{O}_{18.64}, \mathrm{BaMgAl}_{10} \mathrm{O}_{17}$ and $\mathrm{BaMg}_{2} \mathrm{Al}_{16} \mathrm{O}_{27}$ (blue phosphors) and $\mathrm{Ce}_{0.67} \mathrm{~Tb}_{0.33} \mathrm{MgAl}_{11} \mathrm{O}_{19}$ and $\mathrm{Eu}^{2+}, \mathrm{Mn}^{2+}$ doped $\mathrm{BaMgAl}_{10} \mathrm{O}_{17}$ (green phosphors). The results of these investigations are presented in this paper.

\section{Experimental}

\subsection{Preparation of carbohydrazide $\left(\mathrm{CH}_{6} \mathrm{~N}_{4} \mathrm{O}, \mathrm{CH}\right)$}

Carbohydrazide, $\mathrm{N}_{2} \mathrm{H}_{3} \mathrm{CON}_{2} \mathrm{H}_{3}$, was prepared as reported (Arul Dhas and Patil 1994) by the hydrazinolysis of diethylcarbonate using hydrazine hydrate in a 1:2 molar ratio.

\subsection{Preparation of oxalyl dihydrazide $\left(\mathrm{C}_{2} \mathrm{H}_{6} \mathrm{~N}_{4} \mathrm{O}_{2}, \mathrm{ODH}\right)$}

Oxalyl dihydrazide, $\mathrm{N}_{2} \mathrm{H}_{3} \mathrm{COCON}_{2} \mathrm{H}_{3}$, was prepared (Suresh et al 1991) by dropwise addition of 1 mole of diethyl oxalate to 2 moles of hydrazine hydrate dissolved in $225 \mathrm{ml}$ of doubly distilled water. Extra pure urea was used as received for the combustion.

\subsection{Stoichiometric calculation}

The stoichiometric compositions of the redox mixtures for the combustion were calculated using the total oxidizing $(O)$ and reducing $(F)$ valencies of the components as 
reported earlier (Kingsley and Patil 1988). Thus, the oxidizing valencies of divalent and trivalent metal nitrates are -10 and -15 respectively and the reducing valencies of carbohydrazide, oxalyl dihydrazide and urea are $+8,+10$ and +6 respectively. Therefore, the mole ratio of $\mathrm{M}\left(\mathrm{NO}_{3}\right)_{2}$ : urea, $\mathrm{M}\left(\mathrm{NO}_{3}\right)_{2}: \mathrm{CH}, \mathrm{M}\left(\mathrm{NO}_{3}\right)_{3}$ : urea, $\mathrm{M}\left(\mathrm{NO}_{3}\right)_{3}: \mathrm{CH}$ and $\mathrm{M}\left(\mathrm{NO}_{3}\right)_{3}: \mathrm{ODH}$ are $1: 1 \cdot 66,1: 1 \cdot 25,1: 2 \cdot 5,1: 1 \cdot 875$ and $1: 1 \cdot 5$ respectively.

\subsection{Preparation of phosphors}

Rare earth doped lamp phosphors were obtained by rapidly heating an aqueous concentrated solution containing stoichiometric amounts of metal nitrates and a fuel ( $\mathrm{CH}$ or $\mathrm{ODH}$ or urea) at $400-500^{\circ} \mathrm{C}$. The solution, in a $300 \mathrm{~cm}^{3}$ pyrex dish, initially boils, undergoes rapid dehydration and foaming followed by decomposition. generating combustible gases such as oxides of nitrogen, HNCO and ammonia. The volatile combustible gases ignite and burn with a flame yielding voluminous oxides.

\subsection{Physical methods}

The solid combustion products were characterized by powder X-ray diffraction (XRD) pattern to confirm the formation of host lattices, and the presence of activator ions in these host lattices was confirmed by their characteristic fluorescence spectra. The XRD patterns were recorded using a Philips PW 1050/70 X-ray diffractometer with $\mathrm{Ni}$-filter $\mathrm{Cu}-\mathrm{K} x$ radiation. Fluorescence spectra were recorded under the excitation of $254 \mathrm{~nm}$ ultra violet light. Powder density, particle size distribution and surface area were measured to ascertain the particulate properties. A centrifugal photosedimentation method (Micron SKC 2000 photosizer) was used to determine the particle size (i.e. Stokes diameter) distribution of phosphor powders. The powder density was measured using a pychnometer with xylene as the liquid medium. The surface area of fluorescent powders was measured using the nitrogen gas adsorption multipoint BET method (Accursorb $2100 \mathrm{E}$ ) assuming a cross-sectional area of $0.162 \mathrm{~nm}^{2}$ for nitrogen molecule.

\section{Results and discussion}

Doping of host matrices (aluminates and yttria) with desired activator ions $\left(\mathrm{Eu}^{3+}\right.$, $\mathrm{Eu}^{2+}, \mathrm{Ce}^{3+}, \mathrm{Tb}^{3+}$ and $\mathrm{Mn}^{2+}$ ) involves atomic level substitution of ions present in these lattices by activator ions. Such substitutions invariably require high temperatures and long processing time. For example, formation of $\mathrm{Eu}^{3+}$ doped $\mathrm{Y}_{2} \mathrm{O}_{3}$ (red phosphor) is known to take place when the mixture of dry oxide constituents is heated at $\geqslant 1400^{\circ} \mathrm{C}$ for $8 \mathrm{~h}$ (Schaik and Blasse 1992).

Rare earth ions doped aluminous oxides or yttria like $\mathrm{Ba}_{0.64} \mathrm{Al}_{12} \mathrm{O}_{18}: \mathrm{Eu}^{2+}$, $\mathrm{BaMgAl}_{10} \mathrm{O}_{17}: \mathrm{Eu}^{2+}, \mathrm{BaMg}_{2} \mathrm{Al}_{16} \mathrm{O}_{27}: \mathrm{Eu}^{2+}, \mathrm{BaMgAl}_{10} \mathrm{O}_{17}: \mathrm{Eu}^{2+}, \mathrm{Mn}^{2+}, \mathrm{Ce}_{0.67}$ $\mathrm{Tb}_{0.33} \mathrm{MgAl}_{11} \mathrm{O}_{19}$ and $\mathrm{Y}_{2} \mathrm{O}_{3}: \mathrm{Eu}^{3+}$ have been prepared by the combustion of respective metal nitrates - urea/CH/ODH mixtures at $400-500^{\circ} \mathrm{C}$. The solution containing stoichiometric amounts of redox mixture when heated rapidly boils and undergoes dehydration followed by decomposition generating combustible gases such as oxides of nitrogen, $\mathrm{HNCO}$ and $\mathrm{NH}_{3}$ which burn with appearance of flame yielding voluminous 
phosphors. Theoretical reactions, assuming complete combustion, may be written as

$$
\begin{aligned}
& 2-x \mathrm{Y}\left(\mathrm{NO}_{3}\right)_{3}+x \mathrm{Eu}\left(\mathrm{NO}_{3}\right)_{3}+3 \mathrm{C}_{2} \mathrm{H}_{6} \mathrm{~N}_{4} \mathrm{O}_{2}(\mathrm{ODH}) \\
& \stackrel{\Delta}{\rightarrow} \mathrm{Y}_{2-x} \mathrm{Eu}_{x} \mathrm{O}_{3}(\mathrm{~s})+\text { gaseous products }\left(\mathrm{H}_{2} \mathrm{O}, \mathrm{CO}_{2} \text { and } \mathrm{N}_{2}\right) \text {, } \\
& 0.64-x \mathrm{Ba}\left(\mathrm{NO}_{3}\right)_{2}+x \mathrm{Eu}\left(\mathrm{NO}_{3}\right)_{3}+12 \mathrm{Al}\left(\mathrm{NO}_{3}\right)_{3}+23 \cdot 3 \mathrm{CH}_{6} \mathrm{~N}_{4} \mathrm{O}(\mathrm{CH}) \\
& \stackrel{\Delta}{\rightarrow} \mathrm{Ba}_{0 \cdot 64-x} \mathrm{Eu}_{x} \mathrm{Al}_{12} \mathrm{O}_{18 \cdot 64}(\mathrm{~s})+\text { gaseous product }\left(\mathrm{H}_{2} \mathrm{O}, \mathrm{CO}_{2} \text { and } \mathrm{N}_{2}\right) \text {, } \\
& 1-x \mathrm{Ba}\left(\mathrm{NO}_{3}\right)_{2}+x \mathrm{Eu}\left(\mathrm{NO}_{3}\right)_{3}+\mathrm{Mg}\left(\mathrm{NO}_{3}\right)_{2}+10 \mathrm{Al}\left(\mathrm{NO}_{3}\right)_{3} \\
& +28 \cdot 33 \mathrm{CH}_{4} \mathrm{~N}_{2} \mathrm{O}(\text { urea }) \stackrel{\Delta}{\rightarrow} \mathrm{Ba}_{1-x} \mathrm{Eu}_{x} \mathrm{MgAl}_{10} \mathrm{O}_{17}(\mathrm{~s}) \\
& + \text { gaseous products }\left(\mathrm{H}_{2} \mathrm{O}, \mathrm{CO}_{2} \text { and } \mathrm{N}_{2}\right) \text {. } \\
& 1-x \mathrm{Ce}\left(\mathrm{NO}_{3}\right)_{3}+x \mathrm{~Tb}\left(\mathrm{NO}_{3}\right)_{3}+\mathrm{Mg}\left(\mathrm{NO}_{3}\right)_{2}+11 \mathrm{Al}\left(\mathrm{NO}_{3}\right)_{3} \\
& +31.67 \mathrm{CH}_{4} \mathrm{~N}_{2} \mathrm{O}(\text { urea }) \stackrel{\Delta}{\rightarrow} \mathrm{Ce}_{1-x} \mathrm{~Tb}_{x} \mathrm{MgAl}_{11} \mathrm{O}_{19}(\mathrm{~s}) \\
& + \text { gaseous products }\left(\mathrm{H}_{2} \mathrm{O}, \mathrm{CO}_{2} \text { and } \mathrm{N}_{2}\right) \text {. }
\end{aligned}
$$

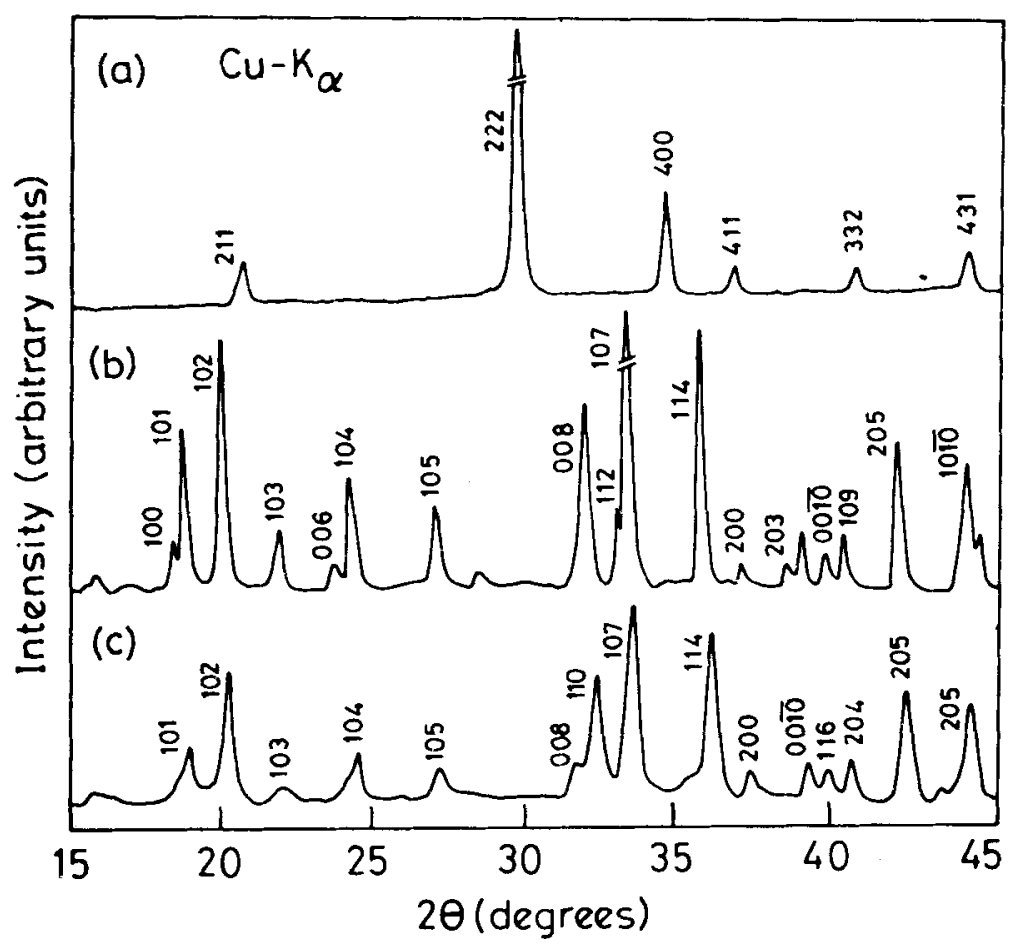

Figure 1. Powder XRD patterns of as-prepared lamp phosphors: (a) $\mathrm{Y}_{2} \mathrm{O}_{3}: \mathrm{Eu}^{3+}$, (b) $\mathrm{Ba}_{0.64} \mathrm{Al}_{12} \mathrm{O}_{18.64}: \mathrm{Eu}^{2+}$ and (c) $\mathrm{BaMgAl}_{10} \mathrm{O}_{17}: \mathrm{Eu}^{2+}$. 

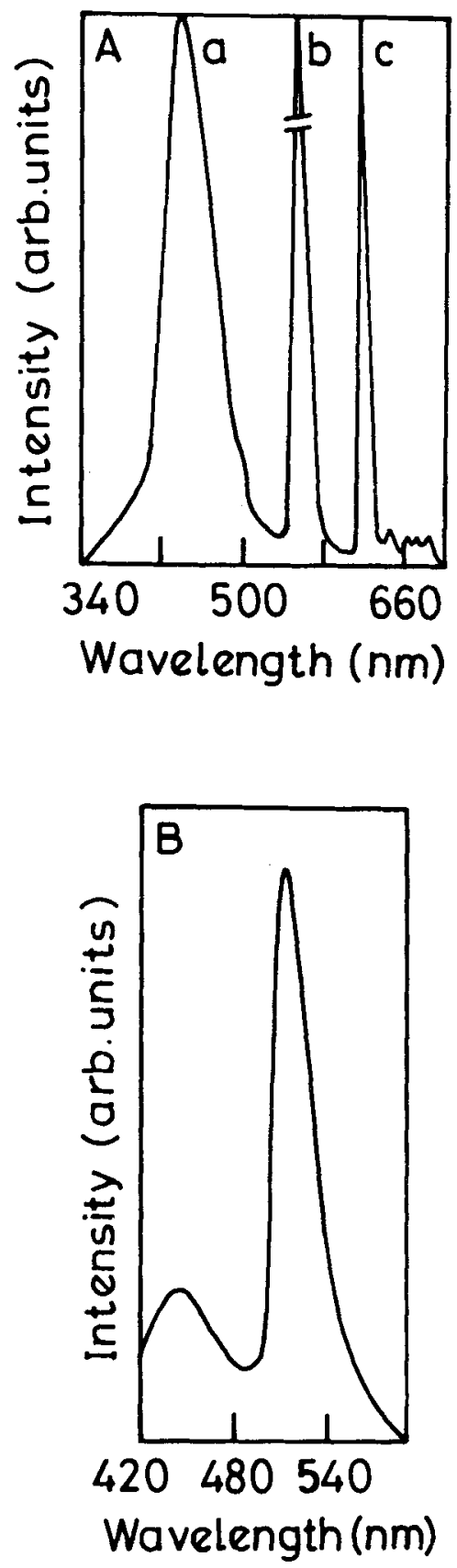

Figure 2. Room temperature fluorescence spectra of: $\mathrm{A}$. (a) $\mathrm{BaMgAl}_{10} \mathrm{O}_{17}: \mathrm{Eu}^{2+}$ (blue), (b) $(\mathrm{Ce}, \mathrm{Tb}) \mathrm{MgAl}_{11} \mathrm{O}_{19}$ (green) and (c) $\mathrm{Y}_{2} \mathrm{O}_{3}: \mathrm{Eu}^{3+}$ (red) and $\mathrm{B}$. $\mathrm{BaMgAl}_{10} \mathrm{O}_{17}: \mathrm{Eu}^{2+}, \mathrm{Mn}^{2+}$ (green).

The large amount of escaping gases dissipate the heat and thereby prevent the oxides from sintering. Also, as the gases escape, they leave voluminous fine powders.

The formation of these phosphors is confirmed by the powder XRD patterns of the combustion residue (figure 1). It can be seen that the powder XRD patterns correspond 
Table 1. Powder X-ray and fluorescence data of lamp phosphors.

\begin{tabular}{|c|c|c|c|}
\hline Phosphors & System & Lattice parameters $(\AA)$ & Emission band $(\mathrm{nm})$ \\
\hline $\mathrm{Y}_{2} \mathrm{O}_{3}: \mathrm{Eu}^{3+}$ & cubic & $a=b=c=10.6148$ & 611 \\
\hline $\mathrm{Ba}_{0.64} \mathrm{Al}_{12} \mathrm{O}_{18 \cdot 64}: \mathrm{Eu}^{2+}$ & hexagonal & $a=b=5.3794, c=23.1984$ & 435 \\
\hline $\mathrm{BaMgAl}_{10} \mathrm{O}_{17}: \mathrm{Eu}^{2+}$ & hexagonal & $a=b=5.6269, c=22.6316$ & 450 \\
\hline$(\mathrm{Ce}, \mathrm{Tb}) \mathrm{MgAl}_{11} \mathrm{O}_{19}$ & hexagonal & $a=b=5.5441, c=21.9382$ & 543 \\
\hline
\end{tabular}

to the respective host materials. The lattice parameters (table 1), refined with a leastsquares fit using powder XRD reflections, are in good agreement with the literature. The presence of activator ions in the host lattices was confirmed by their fluorescence spectra (figure 2). These data have been summarized in table 1.

\subsection{Properties of $\mathrm{Y}_{2} \mathrm{O}_{3}: \mathrm{Eu}^{3+}$ (red phosphor)}

There are two types of yttrium sites (ratio $3: 1$, having local symmetries $\mathrm{C}_{2}$ and $\mathrm{S}_{6}$ ) due to vacancies present in the oxygen lattice. $\mathrm{Eu}^{3+}$ ion has equal probabilities to occupy $\mathrm{C}_{2}$ and $\mathrm{S}_{6}$ sites. The red emission is attributed to the $\mathrm{Eu}^{3+}$ ions at the $\mathrm{C}_{2}$ site.

The redox mixture containing yttrium nitrate, europium nitrate and oxalyl dihydrazide when rapidly heated at $400^{\circ} \mathrm{C}$, ignite and yield voluminous crystalline phosphor (figure 1). The presence of activator ions, $\mathrm{Eu}^{3+}$ in yttrium site was confirmed from fluorescence spectra (figure 2). The emission spectra of the compound shows the characteristic emission at $611 \mathrm{~nm}$ and it proves the formation of red phosphor. That is, $\mathrm{Eu}^{3+}$ ions have occupied $\mathrm{Y}^{3+}$ ions at $\mathrm{C}_{2}$ sites in the $\mathrm{Y}_{2} \mathrm{O}_{3}$ lattice. This characteristic emission band is attributed to the electric dipole transition, ${ }^{5} D_{0} \rightarrow{ }^{7} F_{2}$ of the Eu ${ }^{3+}$ ions. The other emission due to the $\mathrm{Eu}^{3+}$ ions at $\mathrm{S}_{6}$ site also is seen in the emission spectrum. The intensity of the band at $611 \mathrm{~nm}$ is higher than that of the other bands. This is usually observed if product is homogeneous which favours strong energy transfer from $\mathrm{S}_{6}$ to $\mathrm{C}_{2}$. The excitation spectrum of red phosphor showed a band at $245 \mathrm{~nm}$. When $\mathrm{Eu}^{3+}\left(4 f^{6}\right)$ is introduced in the $\mathrm{Y}_{2} \mathrm{O}_{3}$ matrix, it tends to capture an oxygen $2 p$ electrons to go towards the highly stable $4 f^{7}$ configuration (Ropp 1967), responsible for intense excitation band at $245 \mathrm{~nm}$. This excitation process of the luminescent centres is more efficient than energy transfer from the host to the activator, found in many other phosphors.

In order to confirm whether all activator ions, $\mathrm{Eu}^{3+}$, occupied yttrium site or not, asprepared powder was subjected to calcination at different temperatures and the relative intensity of emission peak, $611 \mathrm{~nm}$, was monitored. The relative intensity of the emission peak did not vary much with calcination temperature which indicated that all activator ions, $\mathrm{Eu}^{3+}$, occupied $\mathrm{Y}^{3+}$ site of $\mathrm{Y}_{2} \mathrm{O}_{3}$ matrix in the as-prepared $\mathrm{Y}_{2} \mathrm{O}_{3}: \mathrm{Eu}^{3+}$ phosphor.

\subsection{Properties of $\mathrm{Eu}^{2+}$ doped aluminous oxide (blue phosphor)}

Blue phosphors, $\mathrm{Eu}^{2+}: \mathrm{Ba}_{0.64} \mathrm{Al}_{12} \mathrm{O}_{18 \cdot 64}, \mathrm{Eu}^{2+}: \mathrm{BaMgAl}_{10} \mathrm{O}_{17}$ and $\mathrm{Eu}^{2+}: \mathrm{BaMg}_{2}$ $\mathrm{Al}_{16} \mathrm{O}_{27}$ have been prepared by the combustion of respective metal nitrate-aluminium nitrate-urea/carbohydrazide mixtures containing $\mathrm{Eu}\left(\mathrm{NO}_{3}\right)_{3}$. The formation of $\mathrm{Eu}^{2+}$ 
doped oxides was confirmed by their characteristic powder XRD and fluorescence spectra. Room temperature fluorescence spectra of $\mathrm{Eu}^{2+}$ doped $\mathrm{Ba}_{0.64} \mathrm{Al}_{12} \mathrm{O}_{18.64}$, $\mathrm{BaMgAl}_{10} \mathrm{O}_{17}$ and $\mathrm{BaMg}_{2} \mathrm{Al}_{16} \mathrm{O}_{27}$ showed emission bands at $435 \mathrm{~nm}, 450 \mathrm{~nm}$ and $450 \mathrm{~nm}$ respectively. These results are in good agreement with the literature (Verstegen et al 1974).

Previous studies (Kunzler et al 1992b; Tews et al 1992) showed that UV stability of rare earth doped phosphors depend upon the activator concentration and UV-induced damage of the phosphor decreases with increasing activator concentration. Hence it is worth to know the optimum activator concentration, $\mathrm{Eu}^{2+}$ required to dope in $\mathrm{BaMgAl}_{10} \mathrm{O}_{17}$, without luminescence quenching. The phosphor with activator concentration ranging from $4 \mathrm{~mol} \%$ to $20 \%$ was prepared by the combustion of corresponding metal nitrates and urea at $500^{\circ} \mathrm{C}$. The as-prepared powders showed the single phase crystalline nature. The room temperature fluorescence spectra of all the powder was recorded under the same conditions by exciting at $254 \mathrm{~nm}$ and the relative intensity of the emission peak was monitored. It revealed that relative intensity increased with activator concentration. Above the $16 \mathrm{~mol} \%$ activator concentration, sudden drops in relative intensity was observed. The maximum relative intensity was observed for the $16 \mathrm{~mol} \%$ of activator concentration. The sudden drop in the relative intensity of the phosphors $(\geqslant 16 \mathrm{~mol} \%$ activator concentration $)$ is probably due to the concentration quenching.

\subsection{Properties of $\mathrm{Ce}_{0.67} \mathrm{~Tb}_{0.33} \mathrm{MgAl}_{11} \mathrm{O}_{19}, \mathrm{BaMgAl}_{10} \mathrm{O}_{17}: \mathrm{Eu}^{2+}, \mathrm{Mn}^{2+}$ (green phosphors)}

$\mathrm{Tb}^{3+}$ and $\mathrm{Mn}^{2+}$ cannot be excited directly as the charge transfer band of $\mathrm{Tb}^{3+}$ and $\mathrm{Mn}^{2+}$ lie well above the predominant mercury line $(254 \mathrm{~nm})$. Hence, it is necessary to use suitable sensitizers like $\mathrm{Ce}^{3+}, \mathrm{Eu}^{2+}$ involving intense absorption in this region (254 nm). $\mathrm{Ce}_{0.67} \mathrm{~Tb}_{0.33} \mathrm{MgAl}_{11} \mathrm{O}_{19}, \mathrm{BaMgAl}_{10} \mathrm{O}_{17}: \mathrm{Eu}^{2+}, \mathrm{Mn}^{2+}$ have been prepared by the combustion of respective metal nitrate-aluminium nitrate-urea mixtures at $500^{\circ} \mathrm{C}$. Formation of these phosphors was confirmed by their characteristic powder XRD patterns and fiuorescence spectra. Typical fluorescence spectra of $\mathrm{Ce}_{0.67} \mathrm{~Tb}_{0.33}$ $\mathrm{MgAl}_{11} \mathrm{O}_{19}$ and $\mathrm{BaMgAl}_{10} \mathrm{O}_{17}: \mathrm{Eu}^{2+}, \mathrm{Mn}^{2+}$ are shown in figures $2 \mathrm{~A}$ and $\mathrm{B}$ respectively. They show characteristic emissions at $543 \mathrm{~nm}$ and $515 \mathrm{~nm}$ respectively. In both the cases efficient energy transfer $\mathrm{Ce}^{3+} \rightarrow \mathrm{Tb}^{3+}$ and $\mathrm{Eu}^{2+} \rightarrow \mathrm{Mn}^{2+}$ is observed in leading to strong green emissions. It is noticed that complete quenching of $\mathrm{Eu}^{2+}$ emission is not observed in $\mathrm{BaMgAl}_{10} \mathrm{O}_{17}: \mathrm{Eu}^{2+}, \mathrm{Mn}^{2+}$. All the phosphors when exposed to UV radiation of $254 \mathrm{~nm}$ wavelength show the characteristic red, blue and green colours (figure 3).

\subsection{Particulate properties}

The particulate properties of combustion derived lamp phosphor materials are summarized in table 2 . The powder densities of the combustion products are $50-95 \%$ of the theoretical value. The specific surface areas of lamp phosphors are in the range $5-22 \mathrm{~m}^{2} / \mathrm{g}, \mathrm{Ba}_{0.64} \mathrm{Al}_{12} \mathrm{O}_{18.64}: \mathrm{Eu}^{2+}$ having the highest surface area. The high surface area of lamp phosphors obtained by the combustion process could be attributed to the large amount of cold gases evolved during the combustion which dissipates heat, thereby inhibiting sintering of the combustion product. The specific surface areas of 


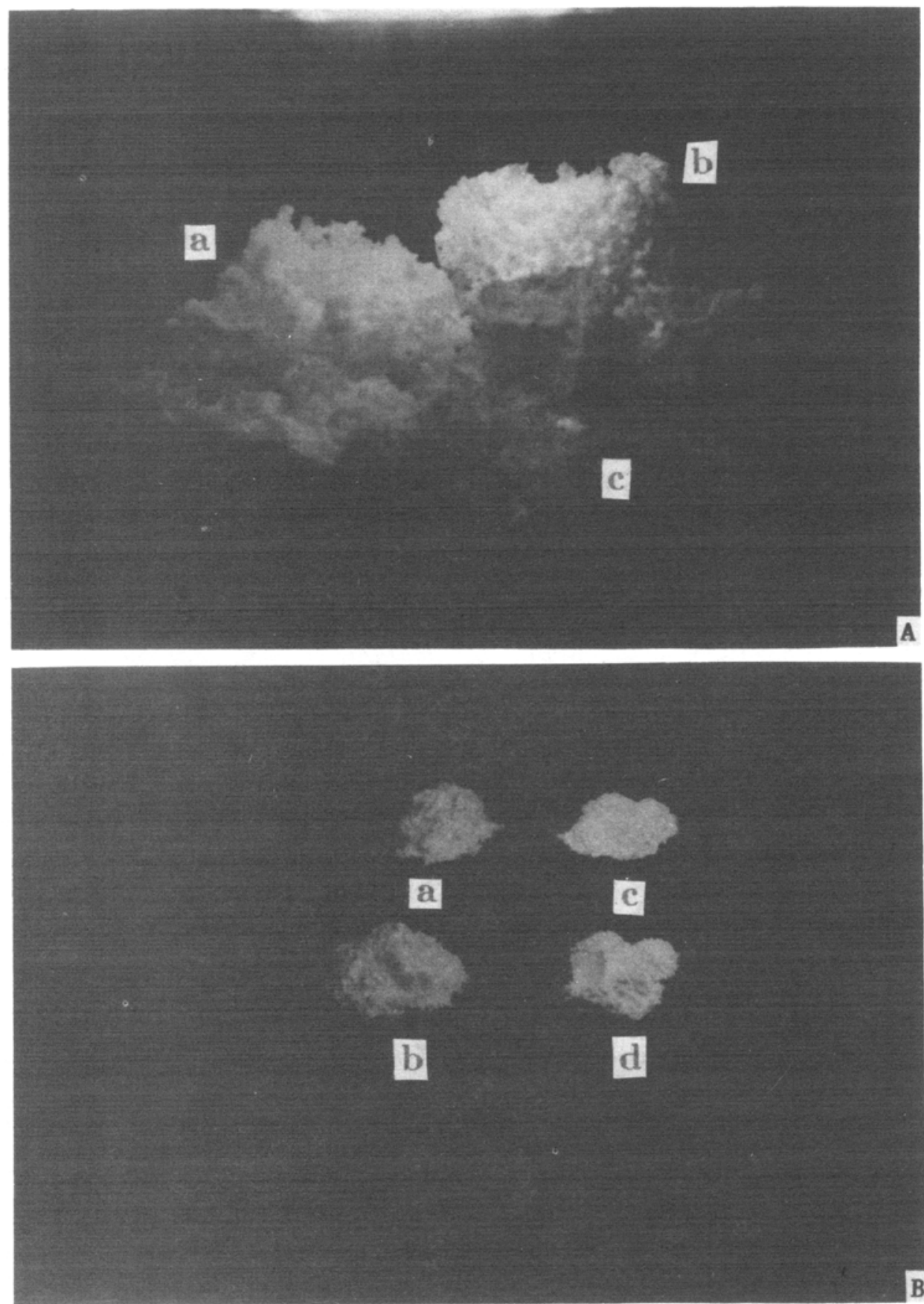

Figure 3. Photographs of UV irradiated red, blue and green phosphors: A. As-prepared foams of (a) $\mathrm{BaMgAl}_{10} \mathrm{O}_{17}: \mathrm{Eu}^{2+}$, (b) $\mathrm{BaMgAl}_{10} \mathrm{O}_{17}: \mathrm{Eu}^{2+}, \mathrm{Mn}^{2+}$ and (c) $\mathrm{Y}_{2} \mathrm{O}_{3}: \mathrm{Eu}^{3+}$ and B. As-prepared powders of (a) $\mathrm{BaMgAl}_{10} \mathrm{O}_{17}: \mathrm{Eu}^{2+}$, (b) $\mathrm{Y}_{2} \mathrm{O}_{3}: \mathrm{Eu}^{3+}$, (c) $\left(\mathrm{Ce}, \mathrm{Tb}^{2} \mathrm{MgAl}_{11} \mathrm{O}_{19}\right.$ and (d) $\mathrm{BaMgAl}_{10} \mathrm{O}_{17}: \mathrm{Eu}^{2+}, \mathrm{Mn}^{2+}$. 
Table 2. Particulate properties of combustion derived lamp phosphors.

\begin{tabular}{llccc}
\hline Compound & $\begin{array}{c}\text { Powder } \\
\text { density } \\
\left(\mathrm{g} / \mathrm{cm}^{3}\right)\end{array}$ & $\begin{array}{c}\text { Surface } \\
\text { area } \\
\left(\mathrm{m}^{2} / \mathrm{g}\right)\end{array}$ & $\begin{array}{c}\text { Particle size } \\
\text { from } \mathrm{S} . \mathrm{A} . \\
(\mu \mathrm{m})\end{array}$ & $\begin{array}{c}\text { Average } \\
\text { agglomerate } \\
\text { size }(\mu \mathrm{m})\end{array}$ \\
$\mathrm{Y}_{2} \mathrm{O}_{3}: \mathrm{Eu}^{3+}(\mathrm{ODH})$ & 4.630 & 19 & 0.068 & 1.42 \\
$\mathrm{Ba}_{0.64} \mathrm{Al}_{12} \mathrm{O}_{18 \cdot 64}: \mathrm{Eu}^{2+}(\mathrm{CH})$ & $2 \cdot 28$ & 22 & 0.119 & $5 \cdot 7$ \\
$\mathrm{BaMgAl}_{10} \mathrm{O}_{17}: \mathrm{Eu}^{2+}$ (urea) & 3.6 & 10 & $0 \cdot 166$ & 8 \\
$\mathrm{Ce}_{0.67} \mathrm{~Tb}_{0.33} \mathrm{MgAl}_{11} \mathrm{O}_{19}$ (urea) & $4 \cdot 10$ & 11 & 0.133 & 9 \\
\hline
\end{tabular}

lamp phosphor prepared by the $\mathrm{CH}$ process are higher than those obtained by the urea process (table 2). This marked difference in surface area and density is attributed to the nature of the fuel which controls the energetics/exothermicity of the combustion reaction. The particulate properties such as density, surface area and particle size appear to depend upon the number of moles of gaseous products liberated during combustion. Assuming complete combustion, 1 mole of $\mathrm{CH}$ gives $6 \mathrm{~mol}$ of gases (5), whereas $1 \mathrm{~mol}$ of urea gives only $4 \mathrm{~mol}$ of gases (6):

$$
\begin{aligned}
& \mathrm{CH}_{6} \mathrm{~N}_{4} \mathrm{O}(\mathrm{CH})+2 \mathrm{O}_{2} \rightarrow \mathrm{CO}_{2}(\mathrm{~g})+3 \mathrm{H}_{2} \mathrm{O}(\mathrm{g})+2 \mathrm{~N}_{2}(\mathrm{~g}), \\
& \mathrm{CH}_{4} \mathrm{~N}_{2} \mathrm{O}(\text { urea })+3 / 2 \mathrm{O}_{2} \rightarrow \mathrm{CO}_{2}(\mathrm{~g})+2 \mathrm{H}_{2} \mathrm{O}(\mathrm{g})+\mathrm{N}_{2}(\mathrm{~g}) .
\end{aligned}
$$

The escaping gases not only make the combustion residue fine but also help to dissipate the heat, thereby preventing the oxides from sintering. Consequently, more porous oxides are expected (large surface area, low powder density and particle size) from the $\mathrm{CH}$ process than the urea process. The lower surface area of the oxides derived from the urea process is probably due to the formation of a stable polymeric intermediates (Kingsley and Patil 1988), which prevents the dissipation of heat, thereby facilitating sintering of the oxides formed during combustion.

The average agglomerate size of $\mathrm{Y}_{2} \mathrm{O}_{3}: \mathrm{Eu}^{3+}$ is $1.42 \mu \mathrm{m}$. The particle size distribution of $\mathrm{Y}_{2} \mathrm{O}_{3}: \mathrm{Eu}^{3+}$ showed that $80 \%$ of the particles are smaller than $1 \mu \mathrm{m}$.

\section{Conclusions}

Rare earth doped lamp phosphors obtained by versatile solution combustion satisfy all the essential requirements of lamp phosphors as stated in the introduction. The formation of homogeneous single phase lamp phosphors not only demonstrates the capability of the combustion process in the atomic level doping of impurity ions in the host lattices but also confirms the highly exothermic (flame temperature $1300^{\circ} \pm 100^{\circ} \mathrm{C}$, measured by an optical pyrometer) nature of combustion. The major advantages of the combustion process are: improvement in processing time, energy saving and the fine particle of the combustion products.

\section{References}

Arul Dhas N and Patil K C 1994 J. Mater. Chem. 4491

Blasse G 1993 J. Alloys \& Compounds 19217

Forest H and Ban G 1971 J. Electrochem. Soc. 1181999 
Hours T Z, Carpin P, Larbot J, Guzard A and Cot L 1992 Ceram. Bull. 71200

Kingsley J J and Patil K C 1988 Mater. Lett. 61988

Koedam M and Opstelen J J 1971 Light Res. Technol. 3205

Kunzler G, Muller B and Tews W 1992a Phys. Status Solidi (a) 130 K279

Kunzler G, Becker P and Tews W 1992b Phys. Status Solidi (a)130 K273

Patil K C 1993 Bull. Mater. Sci. 16533

Patil K C and Sekar M A 1994 Int. J. Self. Prop. High Temp. Synth. 3181

Ramussen M D, Aking M, Milicus D and Mctaggart M G 1985 Ceram Bull. 64314

Rao C N R 1994 Chemical approaches to the synthesis of inorganic materials (New Delhi: Wiley)

Ronda C R and Smets B M J 1989 J. Electrochem. Soc. 136570

Ropp R C 1967 J. Opt. Soc. Am. 57213

Schaik V W and Blasse G 1992 Chem. Mater. 4410

Smets B, Rutten J, Hocks G and Verlijzdonk J 1989 J. Electrochem. Soc. 1362119

Smets B M J and Verlijisdonk J G 1986 Mater. Res. Bull. 211305

Suresh K, Kumar N R S and Patil K C 1991 Adv. Mater. 3148

Tews G, Vater U, Kunzler G, Sasum U and Kloss A 1992 Phys. Status Solidi (a) 130 K131

Verstegen J M P, Radielovic D and Vrenken L E 1974 J. Electrochem. Soc. 1211974

Welker T 1991 J. Luminescence 48 \& 4949 